\title{
Transforming the Teaching and Learning Process in South African Higher Institutions
}

\author{
Noluthando Matola ${ }^{1}$, Kehdinga George Fomunyam ${ }^{2, *}$, Sibusiso Moyo ${ }^{3}$ \\ ${ }^{1}$ Post Graduate Research and Support, Office of the Deputy Vice Chancellor, Durban University of Technology, South Africa \\ ${ }^{2}$ Faculty of Management Sciences, International Center of Non-Violence, Durban University of Technology, South Africa \\ ${ }^{3}$ Deputy Vice Chancellor: Research, Innovation, and Engagement, Durban University of Technology, South Africa
}

Received May 31, 2020; Revised September 12, 2020; Accepted November 5, 2020

\section{Cite This Paper in the following Citation Styles}

(a): [1] Noluthando Matola, Kehdinga George Fomunyam, Sibusiso Moyo, "Transforming the Teaching and Learning Process in South African Higher Institutions," Universal Journal of Educational Research, Vol. 10, No. 1, pp. 67 - 78, 2022. DOI: 10.13189/ujer.2022.100107.

(b): Noluthando Matola, Kehdinga George Fomunyam, Sibusiso Moyo (2022). Transforming the Teaching and Learning Process in South African Higher Institutions. Universal Journal of Educational Research, 10(1), 67 - 78. DOI: 10.13189/ujer.2022.100107.

Copyright $\mathrm{C} 2022$ by authors, all rights reserved. Authors agree that this article remains permanently open access under the terms of the Creative Commons Attribution License 4.0 International License

\begin{abstract}
Teaching and learning is a complex process, which deals with different individuals with different expectations from diverse backgrounds, with different cultural and social capital involved in this process. The teaching and learning process in most South African institutions of higher learning has been plagued by several challenges over the last decade. In this research, the experiences of international postgraduate student lecturers teaching at a university in KwaZulu-Natal were examined. Utilizing the curricular spider web as its framework, it evaluates the experiences of international students lecturing at a university in KwaZulu-Natal, in order to identify the challenges faced by students in this institution during the teaching and learning process, and create a transformation path that can be adopted by other South African institutions of higher learning. This framework utilizes ten different components, each answering some key questions, and all stemming from the rationale for teaching and learning. Using a qualitative case study approach, this research conducted semi-structured interviews involving six participants who were pursuing different postgraduate degrees at the University. Interviews with each participant were conducted in English, lasted about 60 minutes each, and were digitally recorded and transcribed afterwards. Data were analyzed using an open coded process and findings reveal that transforming the teaching and learning process at these institutions of higher learning will largely involve making major changes to the curriculum content, learning activities, and learning
\end{abstract}

resources.

Keywords Teaching, Learning, Higher Education, South Africa, Higher Institutions, Transforming

\section{Introduction}

The role of higher education in Africa's sustainable social, political, and economic development cannot be overemphasized. Higher education can simply be referred to as an organized tertiary learning and training activities and institutions that include conventional universities such as arts, humanities, engineering, technology, etc. professional institutions of learning and training such as colleges of education, and polytechnics are also involved (Alemu, 2018). In these academic environments, scholars are engaged in professional training during the teaching and learning process so as to enable them serve the political, cultural, and socio-economic needs of the society. Teaching and learning is a very complex process which deals with different individuals with different expectations from diverse backgrounds, with different cultural and social capital involved in this process. According to Fomunyam (2014) teachers, and by extension lecturers, must have thorough understanding of the learner in their classroom for effective teaching and learning to take place.

For South Africa, several academic studies have revealed the crisis taking place in these higher institutions 
of learning, leading to very poor academic performance, the inability of students to cope with their course works, and several other issues. The primary aim of this research is to create awareness on some challenges faced by these institutions and their students, by examining the experiences of international post graduate students lecturing at these institutions. This will enable the evaluation of insider perspectives, as these student lecturers interfaces with their students in and out of the classroom. Using a university in the KwaZulu-Natal province of South Africa, this research will analyze these challenges, proffering solutions towards the transformation of the teaching and learning process of these institutions in South Africa.

\section{The South African Higher Education System}

During the colonial era, institutions of higher learning in Africa were considered as campuses of certain universities in the colonial country. For example, the University of London had special campuses in Sierra-Leone (Fourah Bay College), Nigeria (University of Ibadan), Ghana (University of Ghana), and Zimbabwe (College of Rhodesia). These institutions were imperfect clones of the universities in Europe, and their programs reflected the major trends in philosophical discourse and policy debate among the colonial powers (Mohammadbhai, 2008). After independence in the 1960s by several African countries, the struggle to decolonize these institutions of learning from models of European culture to become an education system that is informed by African histories, aspirations, culture and ideas became the topmost agenda (Alemu, 2018). Post Apartheid South Africa is in the forefront of this struggle for transformation in all spheres of its education system, especially higher education.

South Africa has gone through a complex process of teaching and learning since 1994 at the advent of democracy. There have been serious attempts to transform the higher education landscape with issues of access being predominant. Before 1994 a lot of South Africans didn't have access to higher education. With the introduction of democracy, access to higher education was improved, the borders were opened and the universities were gradually transforming. Due to poverty and the lack of opportunities within the nation before 1994, most South Africans who gained access to universities ended their studies at undergraduate level and as such a significant percentage of postgraduates within the universities in South Africa are international students, and many of these international students become tutors or lecturers within South African universities (Mohamedbhai, 2008). It is therefore from this background that this research is informed, owing to the fact that the process they have been engaging in does not only affect teaching and learning but also gives a different perspective since students' experiences constitute an integral part of their postgraduate studies.

As at 2016, South Africa had 26 public higher education institutions, 123 registered private higher education institutions, 50 technical and vocational education and training (TVET) institutions (DHET, 2018). In the same year, enrollment at both public and private higher education institutions (HEIs) reached 1.1 million with 638,001 students enrolled for contact mode of learning, while 33, 836 students enrolled for distance mode of learning.

\section{Framework and Literature Review}

According to Grant and Osanloo (2016), and Landrum, Eaves and Shafto (2015) a theoretical framework is a collection of interrelated concepts that can be used to direct research with the purpose of predicting and explaining the results of the research. This research utilizes the curricular spider web to evaluate the of experiences of international students lecturing at a university in KwaZulu-Natal, in order to identify the challenges faced by students in this institution during the teaching and learning process, and create a transformation path that can be adopted by other South African institutions of higher learning. The curricular spider web, according to Thijs and Van den Akker (2009), is a practical demonstration of what transpires or what should transpire in the classroom. It has nine components, and these components are guided by specific questions which are meant to shape and guide teaching, thereby ensuring that teachers effectively teach the curriculum. The figure below shows the curricular spider web with the key components, as well as accompanying questions. 


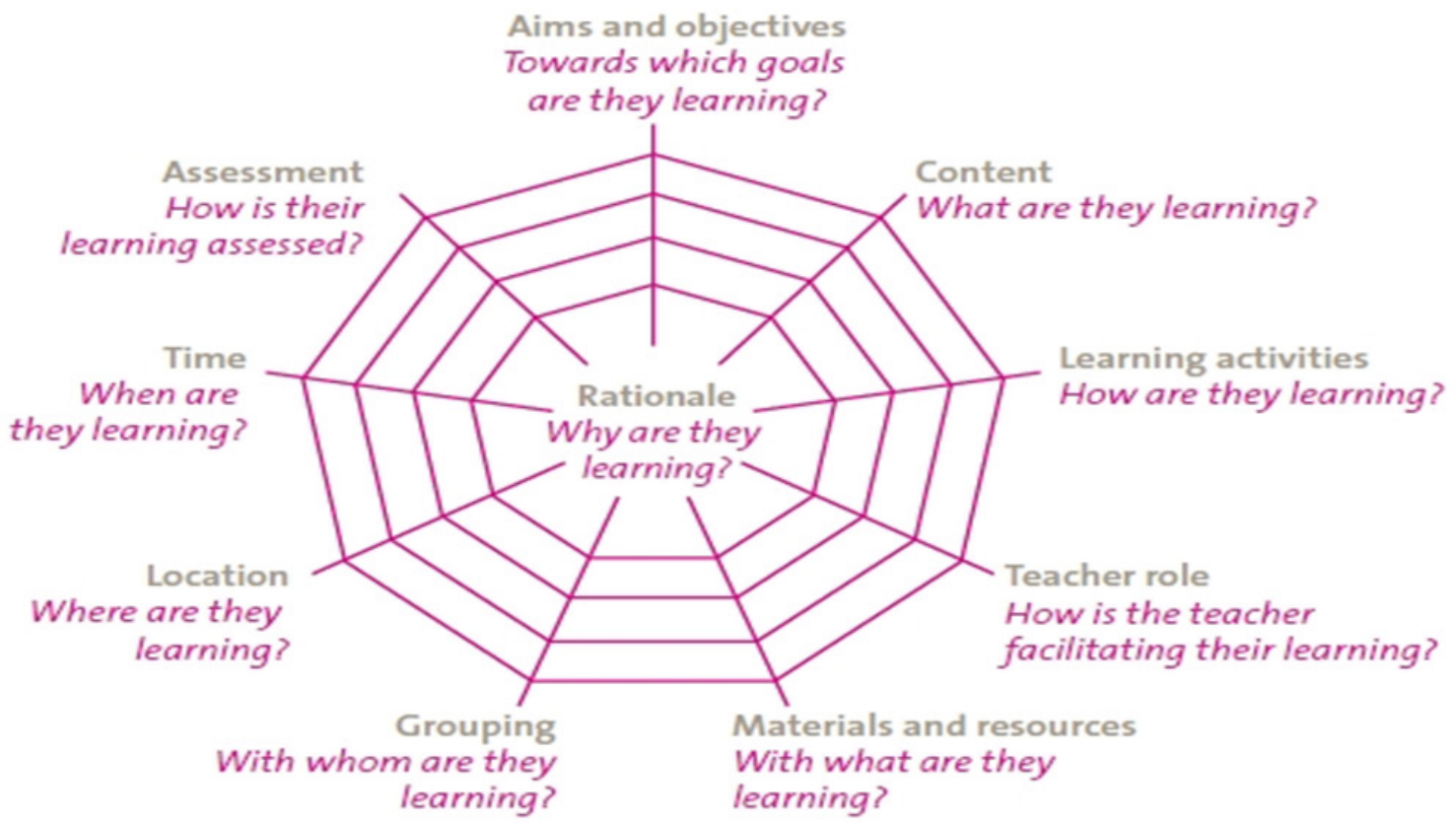

Taken from Thijs and Van den Akker (2009:182).

Figure 1. Curricular Spider Web

This spider web gives direction to teaching and learning by providing key components that work together for successful teaching and learning. Each of these components answer some key questions and all the components stem from the rationale for teaching and learning.

In this research, the theory was adapted to fit the purpose and confines of the research. The adaptation led to the calibration of the key components of the theory as well as the guiding questions. The table below shows the theory as used in this research.

Table 1. Curricular Spider Web

\begin{tabular}{|c|c|}
\hline Key Component & Key Question \\
\hline Rationale or Vision & Why are they teaching and learning? \\
\hline Aims \& Objectives & $\begin{array}{c}\text { Toward which goals are they teaching and } \\
\text { learning? }\end{array}$ \\
\hline Content & What are they teaching and learning? \\
\hline Learning Activities & How are they teaching and learning? \\
\hline Lecturer role & How is the lecturer teaching? \\
\hline $\begin{array}{c}\text { Materials and } \\
\text { Resources }\end{array}$ & With what are they teaching and learning? \\
\hline Grouping & With whom are they teaching and \\
learning?
\end{tabular}

\section{Rationale /Vision}

According to Van den Akker (2009) the rationale of teaching explains the reasons why a teacher teaches.
Studies that have been conducted to find the reasons for teaching indicated that there are various reasons as to why the teachers teach. The rationale of teaching is classified in three levels: Personal rational, societal rationale and Content rationale. A clear understanding of the rationale for teaching will enable the teacher to use various teaching methods. Mpungose (2015) posits that teachers should first identify the rationale before implementing the curriculum in order to have a better understanding of the implementation process.

\section{Aims \& Objectives}

Khoza (2015) emphasizes that it is of utmost importance that the curriculum should state what goals the curriculum implementers want to achieve. This clarity helps the educators to frame their aims and objectives in line with the broader curriculum goals, which in turn helps in shaping the way the subject is taught. Kennedy et al. (2006) identified a shortfall with the objectives in that they are sometimes centered around the lecturer and in some cases centered around the learner an and as result it is not clear whether the objectives are part of teacher-centered approach or learner-centered approach. Berkven et al. (2014) opines that in setting the objectives, it is imperative that attention be given to the perspective of a learner, society and the subject. From the learners' perspective, the learner should be afforded an opportunity for further studying and to secure employment. Also, key competencies like building self-esteem should be developed. From a societal perspective, Berkvern et al. (2014) argue that learners should grow into being assets in society and should be aware of their values and beliefs of 
their respective communities; learners should be able to apply the knowledge acquired in university in ways that are meaningful in their lives.

\section{Content}

Teachers and learners should exhibit proficiency in content knowledge of a subject and must be able to apply the content knowledge to enhance learning. According to Mpungose (2015) a lecturer is regarded as a primary source of the content of the subject, and therefore, the lecturer should master all the different topics being taught. For successful implementation of the curriculum, clear understanding of the content by the lecturer is imperative. What is taught in the classrooms should prepare students for the life ahead, and it should not only make students employable but to also equip students to bring about a positive change in society. Content should be in line with the society, reflecting its realities, which implies that there is a need for the content to be continuously updated because there are constant changes in society, and if the students are to be equipped to match this, then what they are taught needs to be consciously updated.

\section{Lecturing Activities}

According to Norman (2016), learning activities should stimulate learners' desire to learn. Lecturers, therefore, should identify activities that stimulate learner interest and which are fun. Smith and Van Doren (2004) articulate that lecturing activities should enable students to be responsible for their learning, and that each lesson taught to learners must be for a particular purpose and must be transferable outside the classroom. The activities learners engage in should prepare them for local life as well as the world of work (Berkvens et al., 2014), which suggests that lecturing activities should reflect the world of work awaiting the learner. Curriculum Assessment Policy Statement (CAPS) (2011) encourage lecturers to expose their learners to experiences or activities that allow them to talk and think critically. Lecturers are expected to allocate time for individual and group activities, where the lecturer leads the discussions and gives instructions, however, this in nearly impossible in South Africa's large classrooms that are characterized by diverse students. It is even more difficult when the lecturers are not equipped to deal with diversity of students in their classrooms and have limited content knowledge. Mpungose (2015) asserts that informal activities should be used to prepare learners for formal assessments. In other words, informal activities are used to evaluate if the learner has understood what was taught in the classroom. Therefore, because lecturing activities are vital to the preparation of students for formal assessments as well as the world outside the classroom, it then becomes imperative that lecturers be developed in order to master the different teaching activities.

\section{Lecturer Role}

Khoza (2015) established in his study that lecturers were using teacher-centered approach in order to finish syllabus, which suggests that in the case of practical subjects, where learners should engage in practical activities, the learning goals could not be achieved. When a lecturer facilitates learning by allowing learners to construct their own knowledge during the process of instruction, then the approach adopted is learner-centered. According to Sindhu (2012), lecturers have various roles to play in their institutions. These roles involve superintendent, supervisor, a planner, and a controller. The role of a lecturer goes beyond the mere delivery of information; lecturers have to ensure that students know what to do and are doing it at the right time, and are involved in various planning efforts for their institutions, classrooms as well as other activities. Lecturers also have to act as counselors and offer advice to their students in order to ensure their wellbeing. Lecturing involves various roles such as being a good listener, a good leader, a good coordinator, and a good facilitator. Lecturing involves talking and listening, and students' voices must also be heard, which may be a form of feedback to the lecturer on what has been taught and whether learning actually take place or not. Lecturers should also be creative enough to know what kind of activities would stimulate the student and engage them in such activities.

\section{Materials and Resources}

Yara (2010) opines that materials such as textbooks, classrooms, laboratories, libraries, stationery and lecturing aids affect learning. Khoza (2013) classifies resources into three types: hardware resources, referring to any tool or machine used in education for instance computers, chalkboards, worksheets and so on; software, which refers to any material that is used for hardware to display data; and ideological-ware, which refers to the lecturing methods.

Jimenez-Castellanos (2010) states that learning resources can either promote or hinder the ability to develop school culture and high quality instruction. For successful teaching and learning, as well as successful implementation of the curriculum, the availability of sufficient and relevant resources is a necessity (Commonwealth of Learning, 2000). Coleman et al (2003) points out the importance of capacitating lecturers to effectively utilize the teaching/learning resources to ensure successful implementation of the curriculum. The availability of resources does not necessarily guarantee quality teaching. Teaching resources should be suitable for a particular learning environment as well as those benefitting from them. This indicates that learners from well-resourced schools benefit more from the curriculum than those from under-resourced schools. 


\section{Grouping}

Effective teaching and learning requires well planned pedagogical methods. Lecturers are constantly seeking to increase student participation in their classrooms and as such, different modes of delivery are employed. Grouping, or what some called 'team teaching', is one of the modes of delivery commonly used in higher education institutions that has been existence for many years (Carlo-Olson, 1971). He defined 'group teaching' as an instructional situation where two or more lecturers possessing complimentary lecturing skills cooperatively plan and implement the instruction for a single group of students using flexible scheduling and grouping techniques to meet the particular instruction. Bess et al., (2002), concurring with this, defines group teaching as a process with equal involvement and responsibility of all lectures in a team in lecturing and in assessment. From these definitions, it is clear that successful group teaching requires the group to think thoroughly on the content that needs to be taught and allow enough time to plan and prepare for instruction, along with consistent communication and collaboration. Team teaching offers more advantages and can be a very effective approach when utilized properly with team member collectively putting their best efforts in preparation for and delivering instruction. Grouping offers a diversity of expertise and experience on the subject and allows students to learn from experts in different fields. With proper planning and collaboration grouping remains a good method of lecturing.

\section{Location}

Bamford (2008) argues that the main responsibility of higher education institutions is to provide the students with a learning environment that enables the students to develop their knowledge, skills and values. The learning environment plays a major role in ensuring that learning occurs and students are motivated to learn. Shield (2008) concurs with this and argues that the lecturing environment will either facilitate or restrain learning. From the above definition it is clear that the lecturing environment encompasses a range of components, from classrooms or lecture venues, to lecturing resources, cultures, experiences and various other components. Higher education institutions make use of lecture theatres; these are large rooms with a larger capacity than normal classrooms because of the challenge of large class sizes that has been reported to exist in higher education (Opoku-Asare, Agbenatoe \& DeGraft-Johnson, 2014). The learning environment plays a vital role in ensuring productive lecturing, and it should be conducive enough to facilitate learning. Appropriate facilities should be made available if successful teaching and learning is to take place. A lecturer should know which location is necessary for the development of which skill, and the capacity of classrooms where learning takes place should be good enough for the number of students that it has to contain. The location where teaching and learning takes place has a huge impact on teaching and learning and is not a matter to be taken for granted.

\section{Time}

In South Africa, learning periods often run from $8 \mathrm{am}$ to $4 \mathrm{pm}$, except in the case of those who run evening programmes. Student contact time should not only be limited to delivering lessons but should also include time for guidance and provision of feedback to students. The time allocated for lectures may not be enough for learners to ask questions and for the lecturer to identify student requirements and specific needs. One-on-one sessions with students are very essential and allow the lecturer to receive feedback on his/her lessons. Effective teaching and learning is not a matter of hours spent in class but the productive time of teaching and learning. Successful teaching and learning is determined by a number issues including ability of one's body to engage. Learning institution should strive to effectively utilize the time where student are at their peak in the ability to learn. The drawing up of lecture timetables should not be dependent on the availability of the venues but on the nature of the module and the timeframes in which students learning of that module would be at peak.

\section{Assessment}

Bray (2000) defines assessment as a process by which lecturers and learners make judgments about teaching and learning. Simms and George (2014) argue that assessment impacts the students' learning in different ways. Some lecturers view lecturing as merely a transmission of information and as a result, to them, assessment is all about students' ability to reproduce the knowledge acquired. On the other hand, lecturers who view lecturing as facilitation of learning and encouraging critical thinking, see assessment as transformation of knowledge (Samuelowicz $\&$ Bain. 2002). The perspective of lecturers with regards to lecturing largely influences the way in which they assess. Lecturers need to start seeing lecturing beyond a mere transference of facts but as a process that engages the student in their learning, and by so doing, the assessments will encourage critical thinking by the student. Feedback is also an important part of an effective assessment and should be delivered in a manner that is constructive, enabling the students to develop and perform even better

\section{Methodology}

This research adopts a phenomenological approach using a qualitative case study research method in order to gain insights into the challenges encountered in the teaching and learning process of higher education 
institutions in South Africa. Analyzing the experiences of international postgraduate student lecturers at a university in KwaZulu-Natal, this research intends to offer recommendations towards the transformation of the teaching and learning process in these institutions. Detailed interviews with six participants were carried out, and these interviewees were purposefully selected by the researcher. Three participants were pursuing a master's degree, while three others were $\mathrm{PhD}$ students. To ensure a detailed discussion, semi-structured interviews were conducted and participants were asked open-ended questions. This enabled the researcher to allow participants give more detailed responses. Each participant was assured anonymity, and was scheduled to meet with the researcher at a time suitable for both parties. Interviews with each participant was conducted in English, lasted about 60 minutes each, and were digitally recorded and transcribed afterwards.

The data analysis process involved the use of open coded process, after reflections on the points raised by the participants. Open coding, according to Corbin and Strauss (2014), refers to the breaking down of data by the researcher into segments, and searching for relationships within such segments that could represent themes. This is followed by the interrogation of the data with the researcher looking for what is similar or different, and asking questions so that the data is broken down into themes or smaller units which represent different aspects or characteristics of the phenomenon being explored. Data generated were coded and three themes emerged. These themes emerged from the theoretical framework (an adaptation of the curricular spider web) which offered ten specific categories. These themes include learning activities, learning resources, and curriculum content.

\section{Findings and Discussion}

The findings of this research reveal that higher education institutions in South Africa are plagued with several challenges. Channeling a path towards transformation will directly involve the themes which have emerged from this study.

\section{Learning Activities}

These activities include the time allocated for teaching and learning, and the teaching and learning process itself with activities such as grouping. Firstly, time in teaching and learning can be understood in terms of the amount of time specified for a particular lesson or lecture. According to lecturers in this research, allocated time refers to one of the following elements: lecturing time, the time spent on the course, classroom time, time students spend on the subject (engaged time), and dead time. These different measures present various ways of conceiving and using time and not merely time spent in different environments. The postgraduate students interviewed in this research stated that the amount of time allocated for their modules varies for different days and different modules. Explaining this, participant four stated that:

I have lectures in the morning as early as 8 am and also in the afternoon; my last lesson usually finishes at 3:30pm. I teach 2 groups for 4 periods per day 3 times a week. A lesson takes about 45 minutes but it's usually double period.

Time therefore involves various aspects and measures and how a lecturer manages it will determine the effectiveness of teaching and learning. The majority of the participants pointed out that the time allocated for their modules was enough and allowed them an opportunity to engage in other things, including their research work. Lecturing periods often run from $8 \mathrm{am}$ to $4 \mathrm{pm}$, except in the case of those who run evening programmes. Participants pointed out that student contact time is not only limited to delivering lessons but also includes time for guidance and provision of feedback to students. For this reason, this participant avail himself in his office for an hour for student consultation.

Expounding on this, a participant said:

One of the best things with working here is that soon as I am done with my classes I leave. So after the lesson I'm available in my office for like one hour for student consultation but most of the times they do not come. They do not like consulting, even asking questions, they do not even ask question in class when I give them the opportunity to ask questions.

This time gives room for students who would want to clarify certain topics or enquire further about the module because the time allocated for lectures may not be enough for learners to ask questions and for the lecturer to identify student needs. One-on-one sessions with students are very essential, and also allows the lecturer to receive feedback on his/her lessons. In their study Dunn and Dunn (1993) discovered that time of the day affects student learning. They state that the time of day results in differential productivity during different parts of the day due to the circadian rhythm; stamina effects; or school structure effects, for example lower productivity after lunch break. Dunn and Dunn (1993) categorize students into three different types: morning people, afternoon larks, and the night owls. Pope (2016) posits that the different effects at different times of the day may be caused by different factors ranging from changes in teachers quality of teaching, changes in students' learning ability, or differential student attendance. To Rokade and Bahetee (2013), morning sessions are more effective than afternoon sessions. They stated that in the morning their students are more alert and are able to grasp the content, while sessions in the afternoon are less productive as the students are be tired and unable to concentrate. This view was also 
confirmed by the participants in this research, a participant states that:

...in the morning students come to class late because of transport but they participate, but in the afternoon, which is after 1pm, students are tired and cannot concentrate, some will leave early to catch their bus. The best lectures are from 9 am to $11 \mathrm{pm}$.

Another participant also added to this by stating that: Mornings are usually the best sessions because the student is still fresh and able to concentrate. However, for 8am we usually have students coming late, there is a lot of disruption as student will be entering late. Students staying at home always complain about transport to get to the campus early and those ...[staying in] student accommodations also come late as the bus will leave them behind and are forced to take the next bus.

It is clear that there are various issues that affect learning time, and the university needs to evaluate a number of issues when allocating time for lectures. Retention of facts during the morning session is not a good reason for early morning lessons if attendance is poor. Also, the issue of student's residences that are away from campus need to also be taken into consideration. A student who left home in the morning and could not get a chance to rest and eat throughout the day may not be able to concentrate during the afternoon lesson. Moreover, the length of lessons affects student learning, as most students find it difficult to concentrate for two hours and having lecturers cut their lessons short means that the content for that particular session will not be completed. Time can therefore not be decided based on the available time slot, but should consider all these various factors.

As regards the issue of effective learning using the grouping process, this research finds that because of large numbers of students, they work together in teams lecturing the modules in different groups.

Grouping has been defined by Bess et al., (2002) as a process of equal involvement and responsibility of all lectures in a team in lecturing and in assessment. This implies different lecturers working together in lecturing a group of students. Grouping requires frequent and thorough communication among the lecturers in order to produce the required results. Participants in this research confirmed this when they explained that the different groups they lecture have the same assessments that are set by the module coordinator and as such, what is taught in one class has to be the same as what is being taught in the next group. One Participant further explains that:

So at times you have one thousand two hundred first year students and also a similar number for second year students. Those students will then be split into smaller groups that may be 10 or 12 groups depending on how many contract lecturers were employed that year. So each Individual then teaches each of those groups. What is happening in one group has to be what is happening in the other groups so when they are split in those groups the module coordinator then develops a module outline so that for each week all the module lecturers will know what to teach. All lecturers are expected to be teaching the same thing across at the same times. However that of course is not always the case because sometimes you find that some lecturers are faster than others. People are different and their approaches are different so some people will be behind while others are ahead. So every week or once in two weeks we come back as a group teaching a particular module and record feedback among ourselves on what may be the challenges.

Yanamandram \& Noble (2006) asserts that effective grouping requires collaboration and/or involvement by team members in the planning, management and delivery of a subject. Another participant also stated that;

...we can always negotiate if you are one lecturer is struggling to teach a particular topic and another lecturer will come and teach that topic if you feel that students will benefit from that person. From time to time we do invite guest lecturers to come and teach with you and $u$ can teach together. At times you can go and invite someone to teach a particular topic depending on how you want it to be taught. There was a time when we taught like that one of the lecturers in my group invited about four of us we were dealing with the history of education and the four of us were international students so we were to come provide different context about the history of education in different nations because the module dealt with the history of education in South Africa and other countries. So he felt that that what these individuals most of what is written, the details you would not be found in a textbook. So five different lectures were in the same room teaching the same thing but from different angles.

Grouping therefore allows the student to learn from different experts in a particular field, which eases the work of a lecturer, allowing him or her to focus on areas where he or she is strengthened. International students come from different countries and are likely to be limited in teaching particular topics, for example, those that relate to the history of South Africa, and grouping allows them to consult someone who has a better understanding of the country. As one participant explained, certain topics can be well taught by someone who has had particular experience and not just theoretical knowledge.

\section{Curriculum Content}

Pinar (2012) defines content as what is or will be studied in the classroom. He further adds that content 
should answer the following two questions: 'what should be taught?' and 'why it should be taught?' Berkvens et al. (2014) assert that the content of the curriculum should prepare the student for local life, future education and the world of work. International students in this research revealed that they teach various modules within the education division, which suggests that all that students learn in a particular course or module constitutes the content of that module. A participant outlined the content of his modules in this manner:

I lecture professional studies and educational studies. Professional studies aims at giving students practical skills which they would use as teachers in the field. For example one of the professional studies modules I teach focuses on teaching student how to use first aid, we train students to administer first aid which they will use in the class in can when they become teachers and there is an accident so they need an understanding of the basic first aid so that they can begin to administer the respective first aid before help comes. Also another one focuses on different teaching approaches where we show students different teaching approaches, showing them which one to use and when, so that they have a variety of methods to use. There are a broad range of things professional studies do. Professional studies 220, 230 and 240 focuses more on legislation among what teacher should do and not do. While professional studies 210 in as much it also focuses on skills and approaches on teaching, it takes it beyond to cover also a broader range.

Also, another participant explained:

I lecture professional studies where we train the students the different approaches of teaching and also train the student on how to administer first aid. This is very important for teachers to learn because should there be an accident a teacher cannot just stand there hopelessly while waiting for medical officials, he or she has to assist the person injured. We train our students to be able to help a student that unable to breathe, that may be choking, bleeding, or having an asthma attack, has a broken bone, having a seizure, or has a serious injury.

According to these participants, the content taught in his classroom ensures that the students will leave the university more prepared to face the realities facing teachers in different schools. Fomunyam (2015) argues that the content selector should seek to ensure that the content being taught to students adequately represents the realities of the surrounding world. Adding to this, Watony (2012) states that education is supposed to bring freedom, create awareness about the happenings in society and ultimately lead to change, and as such, it is of vital importance that content selectors ensures that the content speaks of the happenings in society.
Marshal (1992) asserts that the concept of learning to allow students to be hands on in acquiring new knowledge, so that they can apply that knowledge in their everyday lives is very important. Marshal (1992) further adds that a teacher must develop these concepts in order to develop students who can learn independently and are able to continue construct knowledge for the rest of their lives. This view suggests that if teachers are to produce the workforce needed by society, in terms of independent and creative thinkers, then they should be able to adopt the necessary teaching methods. Teaching has to move away from a teacher doing all the talk, to involving the student in the process. Nelson (2001) argues that many lecturers maintain the habit of covering the content in the book and their learners continue to memorize it, which is an approach that remains ineffective and inefficient. Nelson (2001) further argues that educators continue re-teaching the same content because despite repeated lessons on the same material, students still don't learn it. Content needs to focus more on students, it should prepare students to succeed in the world of work, help them become responsible and well-informed citizens, and allow them to participate in cultural activities.

\section{Learning Resources}

International students in this research identified the different resources that they used in lecturing their modules. This includes few resources such as a textbook, a laptop, and a projector. One participant had this to say concerning the lecturing resources he uses:

There is a textbook that we use, I use a laptop, and projector for lectures, and sometimes I use the chalkboards because some of the classes I use do not have projectors. However, this has not been the best year because we usually have course packs for students but this year we had no course pack. Students could only access the study material through Moodle. That has limited me in terms of doing activities because student had to check online for the material and in some someday we did not have internet connection and so I had to cancel class activities. Also, having students read material from their cell phones and laptops is disruptive sometimes I will be standing in front of the lecturing and they will be busy with social media.

Information Communication Technology promotes interactive lessons and offers lecturers a sense of confidence when using a variety of lecturing strategies that best achieve the outcomes of the curriculum (Leenderts et al., (2013). In his study, Khoza (2014) argues that Technology in Education promotes teacher-centered teaching. In the teacher-centered approach the lecturer can use a video recorder and record the practical example he or she wants to use in a lesson; the lecturer can then replay and pause it so that the students can analyze the recorded 
examples. The learner-centered approach engages students in discussions that are similar to their everyday lives, and the lecturer may, for example, encourage students to come up with games that they are familiar with, using their everyday knowledge. Participants in this research complained about the issue of time, in that they are unable to use a variety of resources due to time constraints as well as inability to use the latest technologies.

It has been reported in a number of studies one of the challenges facing teaching and learning is the incompetency of lecturers in using new lecturing technologies. In a study by Leendertz et al. (2013) it was stated that lecturers should be competent with the Technology Pedagogical Content Knowledge (TPACK) theory in order to make valuable contributions in teaching and learning. Technological knowledge is defined as ability and skills to use diverse technologies. These technologies include but are not limited to computers, projectors, internet, books, chalk and chalkboards and digital resources to teach the required content. Concurring with this, Khoza (2013a) reveals that the teaching and learning process has to shift for a good reason to be dominated by a combination of the three types of teaching and learning resources (Hardware, Software, and Ideological ware). Pedagogical knowledge refers to the proficiency of teachers in choosing appropriate methods of teaching particular content to learners. Moreover, pedagogical content knowledge is revealed by the lecturer's ability to build on learners' prior knowledge and then adjust their lecturing strategies accordingly to facilitate new knowledge.

In addition to this, two participants identified the challenge of using Moodle instead of course packs. One participant said;

...Students could only access the study material through Moodle. That has limited me in terms of doing activities because student had to check online for the material and in some someday we did not have internet connection and so I had to cancel class activities. Also, having students read material from their cell phones and laptops is disruptive sometimes I will be standing in front of the lecturing and they will be busy with social media.

The other participant also reported a similar situation in his classrooms

I have textbooks I'm using; my challenge is that students come to class without notes. They now access their study material online and they are lazy to download and print when coming to class. It makes it difficult for me teach because they cannot see what I'm teaching. Even when I ask them question most of them they always look like they are not interested all they want is for the lecture to finish and go.

The value of any lecturing resource is on its usefulness in promoting learning. The introduction of Moodle has been reported to be a great development in teaching and learning, however the reported cases in this research means that the use of Moodle needs to be combined with other materials in order to reach all students and ensure learning takes place. The replacement of course material with Moodle is reported by the above participants to be ineffective due to a number of factors, like access - some student are unable to access study material through Moodle because they have no access to internet at home, on campus computers are limited and also some students lack the necessary computer skills. The above participants have expressed the insufficiency of resources as a problem for teaching and learning. The teaching and learning environment is also another important learning resource. Lecturing goes far beyond just a classroom, and includes the university grounds, the library, and the immediate neighborhood of the university (Killen, 2007). Bamford (2008) argues that the main responsibility of higher education institutions is to provide the students with a learning environment that enables the students to develop their knowledge, skills and values; this suggest that the learning environment is important in ensuring that learning actually takes place, and as such, educational institutions should endeavor to provide a learning environment that promotes effective learning. Shield (2008) posits that the lecturing environment will either facilitate or restrain learning. To facilitate learning, Garet et al. (2001) assert that lecturers should be permitted to try out new teaching strategies in the classroom and obtain feedback about their teaching. However, a participant in this research pointed that they are limited in trying certain teaching strategies in their classrooms, as she explained that:

In most cases the classes are always small[er] than the number of students. You sometimes have situation whereby the student are filled up to a point that you cannot even move around, you have to remain in front of the lecture venue. While you are standing in front some students there at the back are doing their own thing, not listening because the slides that we use in class we are expected to also post on Moodle, as such student do not bother listening because they know that they will get the study material at Moodle. Also, some of the venues have built-in furniture, and it becomes impossible to group the students in smaller groups.

A similar experience was reported by another participant who pointed out that:

I lecture in different venues as allocated for that particular module. Some classes are okay especially the fourth years, there is enough space. However I have classes that are big to a point that some students will not have desks to sit on and they will compelled to go fetch desk from the next classrooms. It can be horrible in those classes, even if you feel like it's necessary for the students to engage in group work it can be impossible, I would not even be able to coordinate the groups because there are so many students and I practically cannot move around. 
A challenge of large class sizes has been reported to exist in higher education (Opoku-Asare, Agbenatoe \& DeGraft-Johnson, 2014). In these classes you find up to 700 hundred students being taught by one lecturer. In a class like that, a lecturer is limited in incorporating other teaching strategies like group discussions due to large numbers of students. Lecturers are then forced to take the lead in these classrooms while students are listening. In a study by Blatchford et al. (2004), they found that students in large classes played a more passive role whereas in smaller classes, students were more interactive. A participant reported a challenge with employing continuous assessments in their large classrooms due to the limited resources. She pointed that:

We no longer have the required resources anymore, with the introduction of Moodle, students no longer have course packs, and we can't even do practical work like activities at the end of a unit in language studies. When you teach you have to ask questions and engage the students. If you ask them to open the activities from Moodle from their phones, some will be busy chatting on social media, and some will say that connection is the problem. We have no material to even project in class, in some classes we use we don't even have projectors. Some students complain that they live at home and they do not have laptops, so they have to be on campus to access the material and in most cases they find computers occupied so it becomes difficult for them to access the material. When we had course packs it was easier because at the end of every unit, youwould give the activities and then do corrections together with them. Now they don't have course packs, students simply look at you and you don't even know whether they understand or not.

For this participant, it was not possible to engage the students in continuous assessment because students do not have access to learning material. Learning material is accessed through Moodle and students are expected to print the material out before coming to the classroom but some student come to class without the study material. Bates (2005) argues that while Moodle might look like a tool that is available to all, some student do not have access to computers and stable internet.

Making recommendations, a participant stated:

I would advise the university to add more classrooms, they are no longer accommodating the student, the library also needs to be expanded, students are increasing, and the LANS as well need to be added to accommodate the increasing number of students.

There is a need for the learning environment to be revisited and enhanced to facilitate learning. Libraries and LANS are part of the learning environment and should be of a state that promotes effective teaching and learning. These should be big enough to accommodate the number of students and must be equipped with the right resources required for effective learning.

\section{Conclusions}

Using a qualitative case study research method, this research examined the experiences of international postgraduate student lecturers at a university in KwaZulu-Natal. This was done in order to explore a path towards transforming higher education institutions in South Africa which have been plagued with several challenges overtime. To maintain generalization, this research includes international student lecturers from different countries. Findings reveal that the major challenges faced by these institutions academically includes; inadequate learning resources, overpopulated classrooms, lack of clear understanding of the teaching and learning process by lecturers, the content of the curriculum, and an unsuitable learning environment.

In order to transform the system, this research recommends that the learning environment should be of a state that promotes effective teaching and learning. Classrooms and libraries should be big enough to accommodate the number of students and must be equipped with the right resources required for effective learning. On another hand, the replacement of course material with Moodle is reported by participants of this study to be ineffective due to a number of factors, like access - some student are unable to access study material through Moodle because they have no access to internet at home, on campus computers are limited and also some student lack the necessary computer skills. Therefore, the university should consider other effective avenues of handling course materials. The curriculum content also needs to focus more on students, it should prepare students to succeed in the world of work, help them become responsible and well-informed citizens, and allow them to participate in cultural activities. Lastly, the university needs to evaluate a number of issues when allocating time for lectures.

\section{REFERENCES}

[1] Alemu, S.K. (2018). The Meaning, Idea, and History of University Higher Education in Africa: A Brief Literature Review. Forum For International Research in Education, 4(3): $210-227$

[2] Bates, A. T. (2005). Technology, e-learning and distance education. Routledge.

[3] Bamford, J. K. (2008). Improving international students' experience of studying in the UK. The Economics Network.

[4] Berkvens, J., Van den Akker, J., \& Brugman, M. (2014). 
Addressing the quality challenge: Reflections on the post-2015 Unesco Education Agenda, Netherlands National Commission for UNESCO.

[5] Bess, K.D., Fisher, A. T., Sonn, C.C., \& Bishop, B.J. (2002). Psychological Sense of Community: Research, Applications, and Implications. New York: Springer.

[6] Blatchford, P., Bassett, P., Brown, P., Martin, C., \& Russell, A. (2004). The effects of class size on attainment and classroom processes in English primary schools (Years 4 to 6) 2001 - 2003, Research Brief no. RB605. London: DfES. Retrieved May 112007 from http://www.dfes.gov.uk/ research/data/uploadfiles/RBX13-04.pdf.

[7] Bray, M. (2000). Double-Shift Schooling. Design and Operation for Cost-Effectiveness. International Institute for Educational Planning. Commonwealth Secretariat.

[8] Curriculum Assesment Policy Statement (CAPS). (2011). Guidelines for Responding to Learner Diversity in the Classroom Through Curriculum and Assessment Policy Statements: Grades R-12. Retrieved from: https://www.edu cation.gov.za

[9] Coleman, M., Graham-Jolly, M. \& Middlewood D, (eds) 2003. Managing the Curriculum in South African Schools. London. The Commonwealth Secretariat.

[10] Commomwealth of Learning. (2000). Education Management Development. Retrieved from: https://www.o asis.col.org

[11] Corbin, J., \& Strauss, A. (2014). Basics of qualitative research: Techniques and procedures for developing grounded theory (4th Ed.). Thousand Oaks, CA: Sage Publications

[12] Department of Higher Education and Training (DHET). (2018). Statistics on Post-School Education and Training in South Africa: 2016. Released in March 2018. Retrieved from: https://www.dhet.gov.za

[13] Dunn, R. S., \& Dunn, K. J. (1993). Teaching secondary students through their individual learning styles: Practical approaches for grades 7-12. Prentice Hall.

[14] Fomunyam, K. G. (2014). Curriculum theorizing and individualism: An exploration of the curriculum's relation to the social, personal and political dimensions of schooling. Mevlana International Journal of Education (MIJE), 4(2), 122-131.

[15] Fomunyam, K. G. (2015). Content and Ideology in Literature Modules Taught in a Cameroonian University (Doctoral dissertation, University of KwaZulu-Natal, Edgewood).

[16] Garet, M., Porter, A., Desimone, L., Birman, B., Yoon, K. (2001). What makes professional development effective? Results from a national sample of teachers. American Educational Research Journal, 38(4), 915-945.

[17] Grant, C., \& Osanloo, A. (2016). Understanding, selecting, and integrating a theoretical framework in dissertation research: Creating the blueprint for your "house". Administrative Issues Journal: Connecting Education, Practice, and Research, 4(2), pp. 12-26

[18] Jimenez-Castellanos, O. (2010). Relationship between educational resources and school achievement: A mixed method intra-district analysis. The Urban Review, 42(4), 351-371.

[19] Kennedy, G., Krause, K., Judd, T., Churchward, A. \& Gray, K. (2006). First year students' experiences with technology: Are they really digital natives? Melbourne, Australia: Biomedical Multimedia Unit, The University of Melbourne. Retrieved from http://www.bmu.unimelb.edu.au/research/m unatives/natives_report2006.pdf.

[20] Khoza, S. B. (2013). Learning Outcomes as understood by 'Publishing Research' facilitators at a South African university. Mevlana International Journal of Education, 3(2), 1-11. Available online at http://mije.mevlana.edu.tr/

[21] Khoza, S. B. (2014). Using curricular spider web to explore a research facilitator's and students' experiences. South African Journal of Higher Education, 28(3), 1-14.

[22] Khoza, S. B. (2015). Student teachers' reflections on their practices of the curriculum and assessment policy statement. South African Journal of Higher Education, 29(4), 179-197.

[23] Killen, R. (2007). Teaching strategies for outcomes-based education. Juta and Company Ltd. ISBN: 070217680X, 9780702176807.

[24] Landrum, A. R., Eaves, B. S., \& Shafto, P. (2015). Learning to trust and trusting to learn: A theoretical framework. Trends in Cognitive Sciences, 19(3), 109-111.

[25] Leendartz, V., Blignaut, S., Ellis, S.M., \& Nieuwoud, H.D. (2015). The Development, Validation and Standardizatio of a Questionnaire for ICT Professional Development of Mathematics Teachers. Pythagoras 36(2): 1-11.

[26] Marshall, H. H. (Ed.). (1992). Redefining student learning: Roots of educational change. Ablex Publishing Corporation.

[27] Mohammadbhai, G. (2008). The Effect of Massification on Higher Education in Africa. Retrieved from: https//: www.boomerangbooks.com.au

[28] Mpungose, C. B. (2015). Teachers' Reflections of the Teaching of Grade 12 Physical Sciences CAPS in Rural Schools at Ceza Circuit (Doctoral dissertation, University of KwaZulu-Natal, Edgewood).

[29] Nelson, G. D. (2001). Choosing content that's worth knowing. Educational Leadership, 59(2), 12-16.

[30] Norman, P. C. (2016). Teacher attitudes and perceptions of low and high socioeconomic status students. (Doctoral dissertation, Utah State University, Logan)

[31] Opoku-Asare, N. A., Agbenatoe, W. G., \& DeGraft-Johnson, K. G. (2014). Instructional strategies, institutional support and student achievement in general knowledge in art: Implications for visual arts education in Ghana.

[32] Pinar, W. (2012). What Is Curriculum Theory? (2 ${ }^{\text {nd }}$ Edition $)$ Mahwah, NJ: Lawrence Erlbaum Associates. ISBN-13: 978-0415804110, ISBN-10: 9780415804110

[33] Pope, N. G. (2016). How the time of day affects productivity: Evidence from school schedules. Review of Economics and Statistics, 98(1), 1-11.

[34] Rokade, S. A., \& Bahetee, B. H. (2013). Shall we teach anatomy with chalk and board or PowerPoint presentations? An analysis of Indian students' perspectives and 
performance. Scholars Journal of Applied Medical sciences, $1(6), 837-842$.

[35] Samuelowicz, K., \& Bain, J. D. (2002). Identifying academics' orientations to assessment practice. Higher education, 43(2), 173-201.

[36] Shield, B. M., \& Dockrell, J. E. (2008). The effects of environmental and classroom noise on the academic attainments of primary school children. The Journal of the Acoustical Society of America, 123(1), 133-144.

[37] Simms, M., \& George, B. (2014). Approaching assessment from a learning perspective: Elevating assessment beyond technique. Educational Assessment, Evaluation and Accountability, 26(1), 95-104.

[38] Sindhu, T. (2012). A study of attitude and work commitment of teachers towards teaching profession.

[39] Smith, L.W., \& Van Dore, D. C. (2004). The Reality-Based
Learning Method: A Simple Method for Keeping Teaching Activities Relevant and Effective. Journal of Marketing Education, 26(1),66-74

[40] Thijs, A. \& Van den Akker, J. (2009) Curriculum in Development. Enschede: SLO.

[41] Watony, J. (2012). Politics and Schooling in Cameroon: Nursery through High School. Victoria: Trafford Publishing.

[42] Yanamandram, V. K., \& Noble, G. (2006). Student experiences and perceptions of team-teaching in a large undergraduate class. Journal of University Teaching \& Learning Practice, 3(1), 49-66.

[43] Yara, P. O., \& Otieno, K. O. (2010). Teaching/learning resources and academic performance in mathematics in secondary schools in Bondo District of Kenya. Asian Social Science, 6(12), 126 